\title{
Prevalence of Cysticercosis and Location of Cysticercus in Carcasses of Cattle Slices in Refrigerators in the Northeast Region of Bahia
}

\author{
M.M. Pedreira ${ }^{1}$, L.S.S. Barros ${ }^{2 *}$, A.B. Sandes ${ }^{3}$ and J.A. Lima ${ }^{4}$ \\ ${ }^{1}$ Municipal Inspection Service (SIM), Portal do Sertão, Public Consortium for Sustainable \\ Development, Rua Senador Quintino, 523, Olhos D'Água, 44003-615, \\ Feira de Santana, Bahia, Brazil \\ ${ }^{2}$ Specialist in Animal Health, FSP-USP (1998), MS in Preventive Veterinary Medicine, FCAV- \\ UNESP (2002), PhD in Preventive Veterinary Medicine, FCAV-UNESP (2005). Adjunct \\ Professor IV in undergraduate and postgraduate courses, Department of Agrarian, \\ Environmental and Biological Sciences (CCAAB), Federal University of Recôncavo da Bahia \\ (UFRB), Cruz das Almas, Bahia, Brazil \\ ${ }^{3}$ MS in Animal Science (UFRB), Specialist in Food Hygiene and Inspection, Professor of \\ Inspection and Technology of Milk, Honey and Derivatives, School of Technology and \\ Sciences (FTC), Avenida Artêmia Pires Freitas, SN, Feira de Santana, Bahia, Brazil \\ ${ }^{4}$ O Bicho Veterinary Clinic, Rua Germiniano Costa, 188, Centro, 44025-070, \\ Feira de Santana, Bahia, Brazil \\ *Corresponding author
}

Keywords

Conviction, Inspection, Veterinarian, Prevention

Article Info

Accepted: 04 May 2018 Available Online: 10 June 2018

\section{A B S T R A C T}

In the present study, the prevalence of bovine cysticercosis in 190,461 animals during a three-year period $(2014,2015$, and 2016) was analyzed in a refrigerator situated in the northeast region, Bahia, Brazil. The animals were supplied from the Bahia municipalities. The data were obtained from reports of daily condemnation of bovine carcasses, as a result of the presence of cysts, and viscera, especially the liver and heart, together with the tongue and head of the animals, as well as the origin of cattle. Prevalence of bovine cysticercosis was observed in 1204 animals, and the form of viable cysts was higher $(0.63 \%)$ as viable cysts $(0.005 \%)$, with a preference for the liver $0.46 \%$ and heart $0.14 \%$. With this we conclude that cysticercosis is an important cause of condemnation of viscera and carcasses leading to enormous economic losses. The intervention of the veterinarian in the prevention of cysticercosis should be to interrupt the evolutionary cycle of the parasite, thus reducing, gradually, the frequency of taeniasis in man, the definitive host. 


\section{Introduction}

The United States Department of Agriculture (USDA) states that Brazil has the second largest cattle herd in the world, following India, accounting for $22.5 \%$ of the total world herd. The country was also the second largest beef producer in 2016, which represents $16.3 \%$ of global production (IBGE, 2016). The meat products sector is among the fastest growing sectors in the Brazilian economy, which can be explained by the country's livestock potential. This potential is a consequence of the availability of traditional and important industrial parks, which enable the market to increasingly provide opportunities for the commercialization of Brazilian meat. Compared to the last decades, the country has transformed all its productive chain by investing in herd genetics and reducing age at slaughter.

Concerns regarding the quality of food and services provided have been growing in recent years in both public and private sectors. These concerns are mainly related to production areas, industrialization, and food handling, which affect several aspects of public health.

Providing security and safety is a complex task that involves the production, manufacturing, and marketing sectors, as well as consumers and public authorities. Public authorities are involved in the development of requirements, guidelines, rules, limits, and standards. They act by inspecting, controlling, supervising, and providing health surveillance. Therefore, prevention is still the best option against potential problems that may affect product quality.

One of the most important bovine diseases is cysticercosis, which is caused by the presence of $T$. saginata larvae in tissues. The animals are infected by ingesting viable eggs found in human feces which contaminate the environment (GUSSO, 1997). In contrast, humans develop taeniasis by eating raw or undercooked meat containing live cysticercus (CHAGAS et al., 2008).

The slaughterhouse is an important facility for the diagnosis of diseases, including zoonoses (UNGAR et al., 1990). Slaughterhouse inspection involves the examination of carcasses and organs for abnormal conditions that may somehow limit or hinder the consumption of the product or raw material by humans (Prata and Fukuda, 2001). In addition, inspection aims to protect the industry against economic losses due to the supply of substandard products (INFANTE GIL and COSTA DURÃO, 1990).

Economic losses related to the treatment and condemnation of meat infected with Cysticercus bovis (COSTA AND BRANT, 1964 and FUKUDA, 2003) and costs for diagnosing and treating human taeniasis and cysticercosis (DEWHIRST, 1974) have been reported. Cysticerci are found in myoglobinrich muscles, where there is sufficient tissue oxygenation (KEARNEY, 1970). Therefore, bovine heart, masticatory muscles, and tongue are sites that should be examined during sanitary inspections. The infection can affect different organs and systems, such as the heart, lungs, liver, subcutaneous tissues, skeletal musculature, eyeballs, and central nervous system (CANELAS, 1962). The objective of this study was to verify the occurrence of Cysticercus bovis in several anatomical sites examined by the Inspection Service at a slaughterhouse located in the northeast region of Bahia, given the need to improve diagnostic methods for bovine cysticercosis.

\section{Materials and Methods}

This study was carried out from March to December 2016. The data used for the Control 
group were obtained over a three-year period (2014, 2015, and 2016) from a slaughterhouse that processes approximately 600 animals per day. Inspection of this facility is performed by the State Inspection Service (SIE). The facility is located at latitude 12.198744 and longitude -38.383631 , in the northeast region of the State of Bahia.

The data used in this study include the name and location of the facilities that supplied the batches of animal products, name of the owner, total number of animals slaughtered in each batch, and cases of live $(0.005 \%)$ and calcified cysticerci $(0.63 \%)$ found in the batches evaluated.

The data were obtained from daily condemnation reports. These included data on the bovine carcass destination, cyst location, visceral conviction (especially liver, heart, tongue, and head) and animal origin. The data were tabulated using Microsoft Excel 2016 by compiling the data obtained from daily spreadsheets provided by the SIE for the period from 2014 to 2016. These spreadsheets contained information on the number of animals slaughtered and frequency of cysticercosis according to the supplier of the batch of slaughtered animals.

The animals were slaughtered following the standard production technology, using routine examinations for bovine cysticercosis in the inspection lines (head, tongue, heart, liver, diaphragm, and esophagus).

The slaughterhouse used in this study handles head, viscera, and carcass by making hot iron markings of animal identification numbers on the condyle of the occipital bone (in the head), and wing of the atlas (in the carcass). The viscera and carcass are correlated by their proximity on the air rail, which is automated, keeping a direct relationship between viscera and carcass.
Lesions that are compatible with cysticercosis are initially inspected by macroscopic visualization. When cysticerci are found in the carcass in the inspection lines, the lesions are identified. Half carcasses, viscera, and head, are sent to the Department of Final Inspection (DIF), where they are examined to determine their destinations. If the cysticerci is classified as alive, the carcasses in which they were found undergo cold treatment $\left(-14^{\circ} \mathrm{C}\right)$ or are condemned and sent to the rendering plant in cases of doubts regarding the status of the cysticercus.

A technique recommended by the Regulation of Industrial and Sanitary Inspection of Products of Animal Origin (RIISPOA) is used to inspect cattle for cysticercosis. In this technique, it is stipulated that carcasses severely infested (as evidenced by the presence of one or more cysts in incisions in various parts of the muscular system and in an area corresponding to the size of the palm of a hand) will be condemned. Inspection is carried out by a team of six inspection agents trained to perform post-mortem inspection. Each inspection agent is assigned a specific part of the animal for inspection. The parts of the animal assigned are the head and lower extremities, hinder part of the animal, rear part of the animal, white viscera and spleen, heart and lungs, and liver and kidneys. The inspection is performed under the supervision of a state inspector and a veterinarian. When there is mild or moderate infection, the carcass is partially rejected after careful examination of the heart, masticatory muscles, tongue, diaphragm and pillars, and easily accessible muscles. In these cases, all parts containing cysts should be removed and condemned. The carcasses are sent to cold rooms or de-boned, and the meat is brine-cured for at least 21 days, under conditions that allow its identification at any time. If the number of cysts is extreme, but the infection is not generalized, the carcass will be marked for 
heat sterilization. Carcasses containing a single calcified cyst may be suitable for consumption after the affected part is removed and condemned.

The data were presented using tables and graphs based on the number of animals slaughtered monthly.

Subsequently, the data were descriptively analyzed to determine the percentage of carcasses with cysticercosis considered calcified or alive in the post-mortem inspection during the aforementioned period. The visceral cysticercosis was analyzed and a high prevalence of calcified cysticercosis was observed in the liver during the entire study period.

\section{Results and Discussion}

A total of 190,461 animals were slaughtered and inspected during the study period. Among these, 1,204 animals were infected with a high prevalence of calcified cysticerci (Table 1).

The total frequency of infected animals is within an acceptable range, since the rate of occurrence of cysticercosis in developing countries is between $1 \%$ and $3 \%$ (FAO, 1986). This information is important when considering economic losses and public health issues caused by cysticercosis in Brazil. The occurrence levels of bovine cysticercosis in developed regions, such as North America and some European countries, is only $0.03 \%$, indicating a need for improvements in control policies for this important zoonosis in Brazil.

A higher occurrence of the calcified form is expected when we compare the percentage of live and calcified cysticerci (FERNANDES AND BUZETTI, 2001), as was recorded in this study. The slaughtering of older animals can explain these percentages. Another explanation could be that an infection occurred at least 9 to 12 months prior to slaughter, and subsequently the cysticerci underwent a natural calcification process.

In addition, the calcification of the cysticerci could be explained by treatments with parasiticides (SATHLER 1998 AND CÔRTES 2000). One plausible reason for this treatment is the fact that the State Inspection Service keeps carcasses with viable cysts for 10 or more days for cold treatment (freezing). When this happens, producers receive only $80 \%$ of the total price.

When the Federal Inspection Service identifies an animal with mild infestation of calcified cysts, which under normal conditions means one or two cysts, the carcass receives an "NE" stamp (not for export), is released for national consumption, and the producer receives payment for its full value.

In 2014, a total of five live cysticerci was observed, four found in the liver in August, and one found in the heart in November. A total of 219 calcified cysticerci was observed in the liver, with a prominent increase in October and November. The total number of cysticerci found in the heart was 133, increasing in June, July, and October. In 2015 only one live cysticercus was found in November. Calcified cysticerci are always more frequent in the liver, and their number increased in February, March, and November. In 2016, the occurrence of live cysticerci in the tongue increased when compared to the other years.

According to this study, a higher occurrence of cysticerci was found first in the liver and then in the heart (Figure 1).

Seasonal patterns may be observed when comparing the occurrence during the period ranging from 2014 to 2016 (Figures 2, 3, and 4). 
Fig.1 total bovine infected with live cysticercus in the refrigerator during the years 2014 to 2016

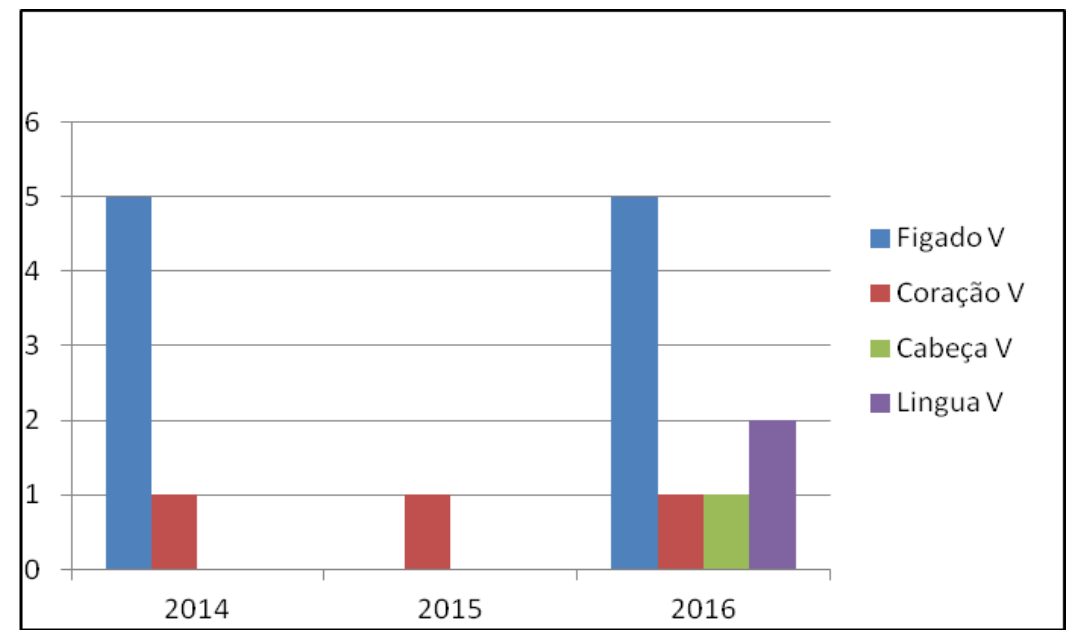

Fig.2 Prevalence of calcified cysticercus found in viscera in cattle during the years 2014 to 2016

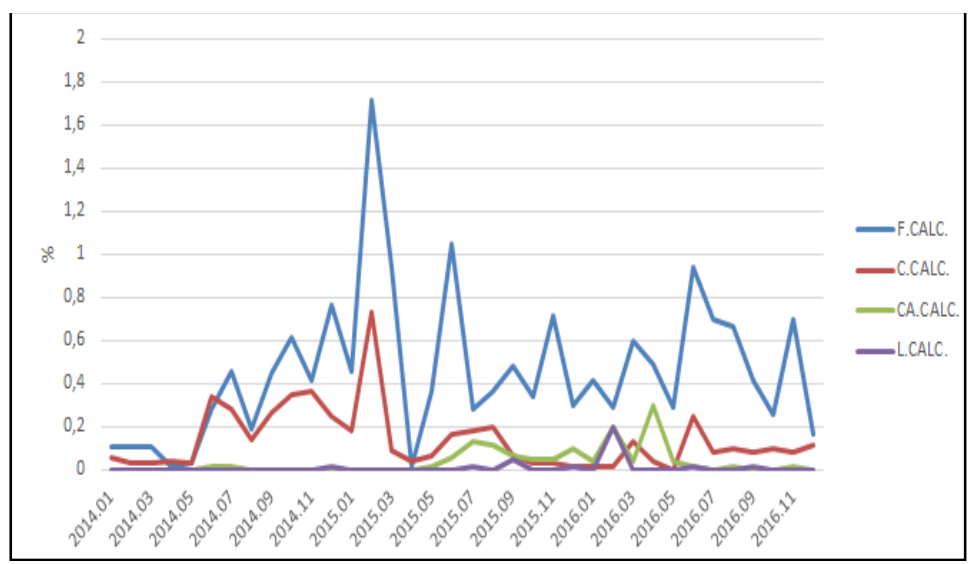

F. Calc $=$ liver calcification; C. Calc. Heart calcification; CA. Calc. = head calcification; L. Calc. = tongue calcification.

Fig.3 Percent calcified cysticercus found in cattle in the fridge over the year total of 2015

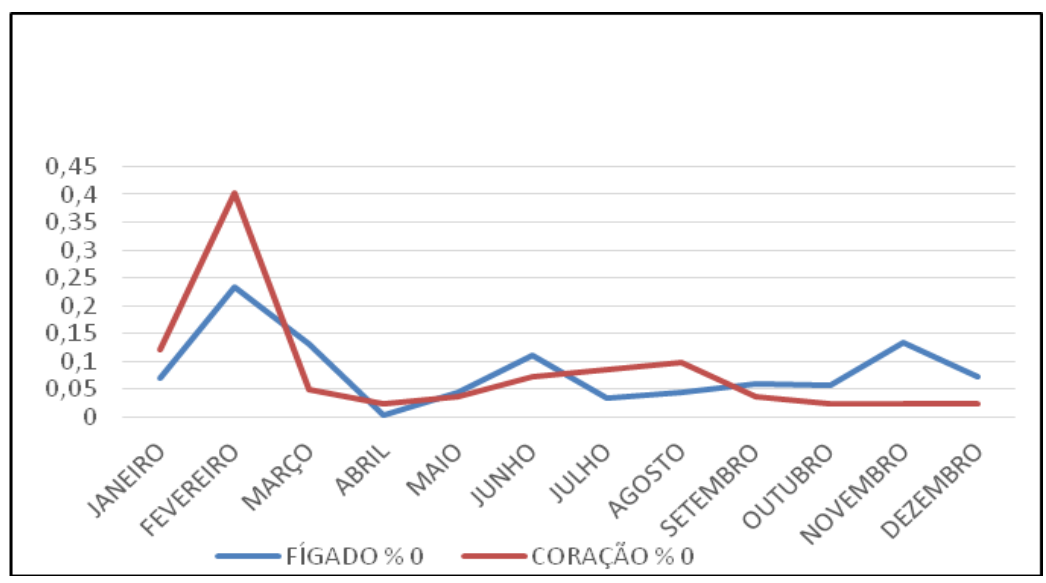


Fig.4 Percent calcified cysticercus found in cattle in the fridge over the year total of 2016

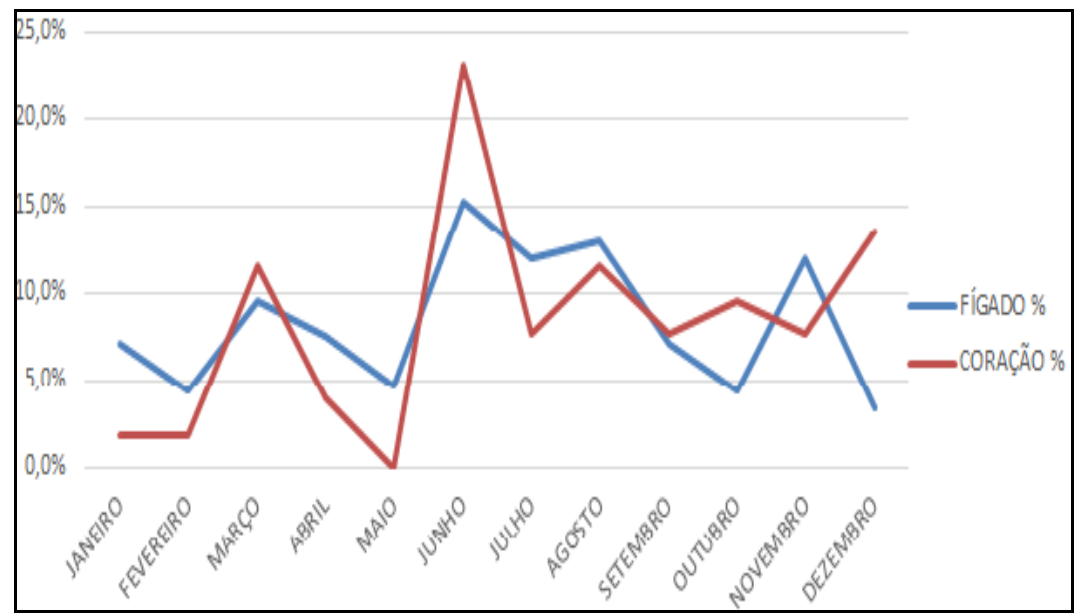

Table.1 Prevalence of live and calcified bovine cysticercosis in a slaughterhouse from 2014 to 2016

\begin{tabular}{|c|c|c|c|c|c|}
\hline Year & $\begin{array}{c}\text { Total } \\
\text { slaughtered } \\
\text { animals }\end{array}$ & $\begin{array}{c}\text { Total } \\
\text { infected } \\
\text { animals }\end{array}$ & $\begin{array}{c}\text { Total } \\
\text { frequency } \\
\%\end{array}$ & $\begin{array}{c}\text { Calcified } \\
\text { frequency } \\
\%\end{array}$ & $\begin{array}{c}\text { Live } \\
\text { frequency } \\
\%\end{array}$ \\
\hline $\mathbf{2 0 1 4}$ & 71,608 & 361 & 0.51 & 0.5 & 0.008 \\
\hline $\mathbf{2 0 1 5}$ & 59,231 & 446 & 0.76 & 0.75 & 0.002 \\
\hline $\mathbf{2 0 1 6}$ & 59,622 & 397 & 0.66 & 0.65 & 0.006 \\
\hline Total & 190,461 & 1,204 & 0.64 & 0.63 & 0.005 \\
\hline
\end{tabular}

Peaks of cysticerci were recorded in the liver in July and October 2014. The number of cysticerci found in the liver and heart was constant in the first five months of the year, but subsequently increased in June and October.

Divergent results concerning the months with higher occurrence were recorded in 2015. Peaks of cysticerci occurrence was recorded in the first two months of the year and remained constant during the rest of the year.

There was a significant increase in the number of calcified cysticerci in the liver $(15.2 \%)$ and heart $(23.1 \%)$ in June 2016 (Figure 4). The low occurrence of cysticerci in the tongue could be because the State Inspection Service does not require this organ to be cut on site in the studied slaughterhouse during examination. Therefore, the inspection is visual and by palpation, except when the carcass is sent to the Department of Final Inspection, where it is meticulously analyzed.

The high prevalence of cysticercosis causes prominent economic losses as a result of the total condemnation or conditional treatment of carcasses, and total condemnation of organs, as observed in this study.

In addition, since standardized inspection methods are limited to superficial incisions in specific locations and in easily accessible muscles, the inspection data provided cannot be fully reliable (BRASIL, 1996) with regard to the quality of meat released for consumption. 
A higher incidence of viable cysticerci was observed in the winter season. This infection is often underestimated because of difficulties experienced during clinical diagnosis and post-mortem examination. However, both the Pan American Health Organization and the World Health Organization consider the taeniasis-cysticercosis complex in Latin America to be an important public health issue, with endemic rates of $1 \%$ for taeniasis, and $0.1 \%$ and $5 \%$ for cysticercosis in humans and animals, respectively (PATGE, 2004). Thus, the prevalence of cysticercosis in slaughtered animals suggests endemic parasitism in the area occupied by the slaughterhouse.

Good practices can interfere with the epidemiological cycle at several time points in the diagnosis of infected humans during the health evaluation of employees involved in the production process, eliminating possible sources of infection. Controlling the quality of food and water made available to the animals, preventing animals from access to rivers and other fountains, and preventing the use of contaminated water for pasture irrigation are also good practices.

Other important practices include the construction of suitable places for defecation, such as septic tanks, and the removal and treatment of employees with taeniasis.

This disease is of a great scope, but can be prevented in humans by simple control measures. The consumer should be informed about preventive measures, such as not eating raw or rare meat, as well as washing, mechanically cleaning, and sanitizing food (vegetables and fruits) before consumption to avoid taeniasis and cysticercosis (OWEN, 2006). Cysticercus can become inactive in food when it is cooked or boiled above $90{ }^{\circ} \mathrm{C}$ for four hours, or when frozen at $-5{ }^{\circ} \mathrm{C}$ for four days.
Implementing the HACCP is mandatory in all establishments which process food of animal origin registered in the SIF. Therefore, slaughterhouses should use the GAPs as a quality management tool for cattle suppliers, encouraging their implementation, monitoring, and auditing of all processes to obtain an innocuous product.

It is essential to educate cattle suppliers of all sizes and with different quality standards on implementing and keeping auditable records to properly raise animals while respecting social, environmental, health, and ethical aspects of livestock production. GAPs is a tool that is used to implement the HACCP Program. Prevention of the occurrence of diseases during the cattle farming process is recommended.

Human taeniasis is a mandatorily notifiable disease, and its incidence is usually estimated by the sales of specific drugs for treating it, with incidence rates ranging from $0.01 \%$ to 10\% (CABARET et al., 2002). Lopes et al., (2011) stated that bovine cysticercosis does not present high clinical importance for beef and dairy farming, since the animals usually present moderate infections and absence of signs. However, these authors highlight that there are economic losses for the producers at the slaughterhouse due to discounts in the price or the condemnation of carcasses diagnosed with cysticerci in the slaughter line.

The Brazilian Ministry of Health (2006) also recommends the use of sanitary barriers in cases of outbreaks, with the identification and treatment of parasitized individuals, animals with cysticercosis, and relatives affected.

After analyzing this study's results, we concluded that cysticercosis is an important cause for the condemnation of bovine viscera and carcasses from animals slaughtered under the State Inspection Service, generating 
significant economic losses, with a high occurrence of calcified cysticerci in the liver and heart. A more thorough inspection is necessary, and not only visual examination and palpation. Inspections must be correlated with laboratory diagnosis to ensure better efficiency in controlling the quality of meat offered in the consumer market.

The improvement, implementation, and inspection of sanitary programs in cattle farming is necessary. These can be used as tools for preventing and controlling diseases.

Several methods can be used to reduce the coverage of this parasitosis. They include the treatment of parasitized humans; sanitary education, mainly among children, since they play a significant role in transforming the society; investment in public health policies; elimination of illegally acquired meats, as they are not inspected by veterinarians; and reduction in the consumption of raw or rare meat.

\section{References}

Acha, P., Szifres, B. 1986. Zoonosis y enfermedades transmisibles comunes al hombre y a los animales. 2 ed. Washington: OPS/OMS, pp. 989.

Bavia, M.E., Carneiro D.D.M.T., Cardim L.L., Silva M.M.N. \& Martins M.S. 2012. Estatística espacial de varredura na detecção de áreas de risco para a cisticercose bovina no estado da Bahia. Arq. Bras. Med. Vet. Zootec. 64, 12001208.

BRASIL, Ministério da Agricultura, Pecuária e Abastecimento. Bovinos e Bubalinos. 2013. Disponível em: http://www. agricultura.gov.br/animal/ especies/ bovinos-e-bubalinos. Acesso em: 20/07/2016

BRASIL, Ministério da Saúde, Fundação Nacional da Saúde. 1996. Projeto para o
Controle do Complexo teníase/cisticercose no Brasil. 53f.

Cabaret, J., Geerts, S., Madeline, M., Ballandonne, C., Barbier, D. 2002. The use of urban sewage ludge on pasture: the cysticercosis threat. Vet. Res. 33, 575-597.

Canelas, H.M. 1962. Neurocisticercose: incidência, diagnóstico e formas clinicas. Arq. Neuropsiq. 20, 1-16.

Chagas, L.G.S., Lopes, E.F., Manzan, N.H., Santos, M.C.D., Nascimento, A.F., Oliveira, L.S.R., Almeida, L.P. 2008. O complexo teníase-cisticercose em pequenas propriedades rurais em Uberlândia-MG. In: VIII ENCONTRO INTERNO E XII SEMINÁRIO DE INICIAÇÃO CIENTÍFICA DA UNIVERSIDADE FEDERAL DE UBERLÂNDIA， 2008, Uberlândia. Anais. Uberlândia.

Côrtes, J.A. 2000. Complexo Teníase Humana-Cisticercose Bovina e Suína IICisticercose Bovina e Suína. Revista de Educação Continuada, 3, 61-71.

Costa, A.S. and Brant, P.C. 1964. Aspecto econômico da cisticercose bovina. Arq. Esc. Vet. 16, 361-371.

Dewhirst, L. W. 1975. Aspectos parasitológicos y económicos de la cisticercose en lãs Americas. Washington: Organizacion Panamericans de la Salud, pp. 143-150.

FAO (Food and Agriculture Organization). Animal Health Yearbook 1986. Animal Production and Health Series, 26.Roma: FAO, 1986, pp. 51.

Fernandes, J. O. M. and Buzetti, W. A. S. 2001. Prevalência de Cisticercose Bovina em animais abatidos em frigoríficos sob Inspeção Federal, da $9^{a}$ região administrativa de Araçatuba, SP. Revista Higiene Alimentar, 15, 30-37, agosto.

Fukuda, T. R., Prata, L. F., Verardino, H., Almeida, L. A. M. 2003. Evolução da 
Cisticercose Bovina em Animais Abatidos no Estado de São Paulo. Revista Higiene Alimentar. 17, 21-31.

Gusso, R.L.F. Teníase e Cisticercose. 1997. Revista Brasileira de Parasitologia Veterinária, São Paulo, 6, 457-463, mês. Infante Gil, J. and Costa Durão, J. 1990. Introduction. In: A colour atlas of meat inspection. Lisboa: Fundação Calouste Gulbenkian, 453.

Kearney, A. 1970. Cysticercus bovis some factors which may influence cyst distribution. Journal Parasitology. 56, 183.

Lopes, W.D.Z., Santos, T.R., Soares, V.E., Nunes, J.L.N., Mendonça, R.P., Lima, R.C. A., Sakamoto, C.A.M., Costa, G.H.N., Thomaz-Soccol, V.T., Oliveira, G.P. and Costa, A.J. 2011. Preferential infection sites of Cysticercus bovis in cattle.

MANUAL de vigilância ativa de doenças transmitidas por alimentos/ Taenia saginata/Teníase. 2002. São Paulo. Disponível em: Acesso em: 18/06/2016
Ministério Da Saúde. 2006. Doenças Infecciosas e Parasitárias: guia de bolso. 6 ed. Brasília: Ministério da Saúde.

Owen, I.L. 2006. Current status of Taenia solium and cysticercosis in Papua New Guinea. Parasitol. Int. 55, S149-S153.

PATGE. Anatomia patológica da cisticercose. 2004. Disponível em: <http://www. fmtm. $\quad$ br/instpub/fmtm/patge/ cisticercose. htm.> Acesso em: 12/07/2016

Prata, L.F., Fukuda, R.T. Santos, D.V. et al., 2001. Análise dos principais Fundamentos de Higiene e Inspeção de carnes. São Paulo, Jaboticabal: Funep, pp. $5-11$

Sathler, I. 1998. Cisticercose bovina: a mais nova velha doença. A Lavoura, 100, 3033.

Ungar, M.C. et al., 1990. O valor dos registros de matadouros para Saúde Pública. Revista Científica da Faculdade de Veterinária da USP, São Paulo, 14, 161-165.

\section{How to cite this article:}

Pedreira, M.M., L.S.S. Barros, A.B. Sandes and Lima, J.A. 2018. Prevalence of Cysticercosis and Location of Cysticercus in Carcasses of Cattle Slices in Refrigerators in the Northeast Region of Bahia. Int.J.Curr.Microbiol.App.Sci. 7(06): 775-783. doi: https://doi.org/10.20546/ijcmas.2018.706.090 